\title{
Anthropogenic effects and salt marsh loss in the Mondego and Mira estuaries (Portugal)
}

\author{
Paula Castro and Helena Freitas
}

Castro, P. and Freitas, H. 2006 Anthropogenic effects and salt marsh loss in the Mondego and Mira estuaries (Portugal) - Web Ecol. 6: 59-66.

\begin{abstract}
Recent decades have witnessed marked losses of coastal wetlands worldwide, but consistent data on salt marsh area are not available. The main goal of this study was to provide information on two Portuguese estuarine habitats (Mondego and Mira) over a period of four to six decades, and to assess how anthropogenic activities have altered the salt marsh ecosystem. Chronological sequences of aerial photographs covering a period of 54 years (1947-98) and 38 years (1958-95) for the Mondego and Mira estuaries, respectively, were considered for this study. Long-term changes in the Mondego estuary revealed a clear decline in the salt marsh area during the past six decades due to urban and industrial expansion. In contrast, the Mira estuary salt marshes remained almost unchanged since 1958. This ecosystem is relatively undisturbed by anthropogenic activities, and marsh variation seems to follow natural dynamics rather than being vulnerable to anthropogenic pressure. The sustainable management of salt marshes must be a priority concern to ensure the long-term viability of their ecological, economic and social capital.
\end{abstract}

P. Castro (pcastro@ci.uc.pt), Dept. of Botany, University of Coimbra, Calçada Martim de Freitas, 3000 Coimbra, Portugal.

Salt marsh habitats and seagrass communities are highly productive ecosystems with a total biomass production ranging from 0.008 to $11.34 \mathrm{~g} \mathrm{DW} \mathrm{m}^{-2} \mathrm{~d}^{-1}$ and ca. $2.5 \mathrm{~g} \mathrm{DW} \mathrm{m}^{-2} \mathrm{~d}^{-1}$ at $40^{\circ}$ latitudes (Duarte and Chiscano 1999). Thus, they play an important role in estuaries in terms of the added-value that they provide (Constanza et al. 1997). Coastal salt marshes have been historically subjected to human influence (Allen 2000), which has transformed them directly and intensively in many ways for a variety of purposes. Human-induced changes to coastal watersheds have affected natural biogeochemical cycles through food and energy production, disturbing the structure and functioning of coastal and marine ecosystems, reducing biodiversity, and the income from activities such as fishery and tourism (Vitousek et al. 1997, Bowen and Valiela 2001, Anon. 2001, Bertness et al. 2002).

Major environmental pressures in the marine ecosystem of Mediterranean and European countries include changing farming and forestry practices that influence the contents of run-off water to estuarine and coastal waters, urban and industry development and associated pollution effluents, solid waste production, eutrophication, biological invasions, exploitation of marine resources, and mass tourism (Anon. 2001, Anon. 2005, Anon. 2006, Anon. 2006). Erosion problems are also important issues concerning these areas and all European coastal countries are, to some extent, affected by coastal erosion. The area lost, or seriously impacted, by erosion is estimated to be $15 \mathrm{~km}^{2}$ 
$\mathrm{yr}^{-1}$ (in 2001), affecting almost 30\% of the Portuguese coast (Anon. 2004). Recent decades have witnessed a marked loss of coastal wetlands, including the USA (Short and Burdick 1996, Schwimmer 2001) and Europe (Cooper et al. 2001, Castillo et al. 2002, Cox et al. 2003) related to human development and climate change (Adam 2002).

Despite the very long history of salt marsh studies, reliable data on salt marsh area are not available in Portugal. We are not aware of any study concerning salt marsh spatial evolution in the Portuguese coastal estuaries. However, to preserve the salt marsh systems it is important to know their distribution, abundance, cover and changes taking place. Monitoring salt marshes is critical to understand their dynamics and to ensure an effective management of these ecosystems. The use of aerial photography provides an opportunity to quantify and detect spatial patterns at large scales. It is a relatively inexpensive technique and a well-established source of information within coastal studies (O’Regan 1996, Ekebon and Erkkilä 2003, Mas 2004) and it has been the preferred methodology for identification and mapping of salt marsh and seagrass loss (Klemas et al. 1993, Robbins 1997, Udy et al. 1999). It is also a useful tool to observe coastal physiographical evolution (Cunha et al. 1997, Jiménez et al. 1997, Dinis and Cunha 1999). Ekebon and Erkkilä (2003) provide detailed information on application of high altitude aerial photographs for identifying and mapping marine and coastal habitats.
The objective of this study was to quantify long-term changes in two Portuguese salt marshes using series of chronological sequences of aerial photographs covering a period of $54 \mathrm{yr}(1947-98)$ and $38 \mathrm{yr}$ (1958-95) for the Mondego and Mira estuaries, respectively. We describe the main anthropogenic activities in each estuarine watershed and discuss how subsequent effects may have contributed to these changes.

\section{Methods}

\section{Study areas}

Two temperate estuaries (Mondego and Mira) were considered for this study. The Mondego estuary (Fig. 1) is located in the centre of Portugal, between $40^{\circ} 08^{\prime} \mathrm{N}$ and $8^{\circ} 50^{\prime} \mathrm{W}$; it is extended about $26 \mathrm{~km}$ from the river mouth until Montemor-o-Velho.

Near the setting of Cinco Irmãos, between Vila Verde and Lares, the river is divided in two arms, north and south, separated by the Murraceira Island, with distinct sedimentology and hydrodynamic characteristics (Dinis and Cunha 1999). Salt marsh mapping was performed after this river bifurcation point and included two subsystems (approximately until $5 \mathrm{~km}$ from the coast line).

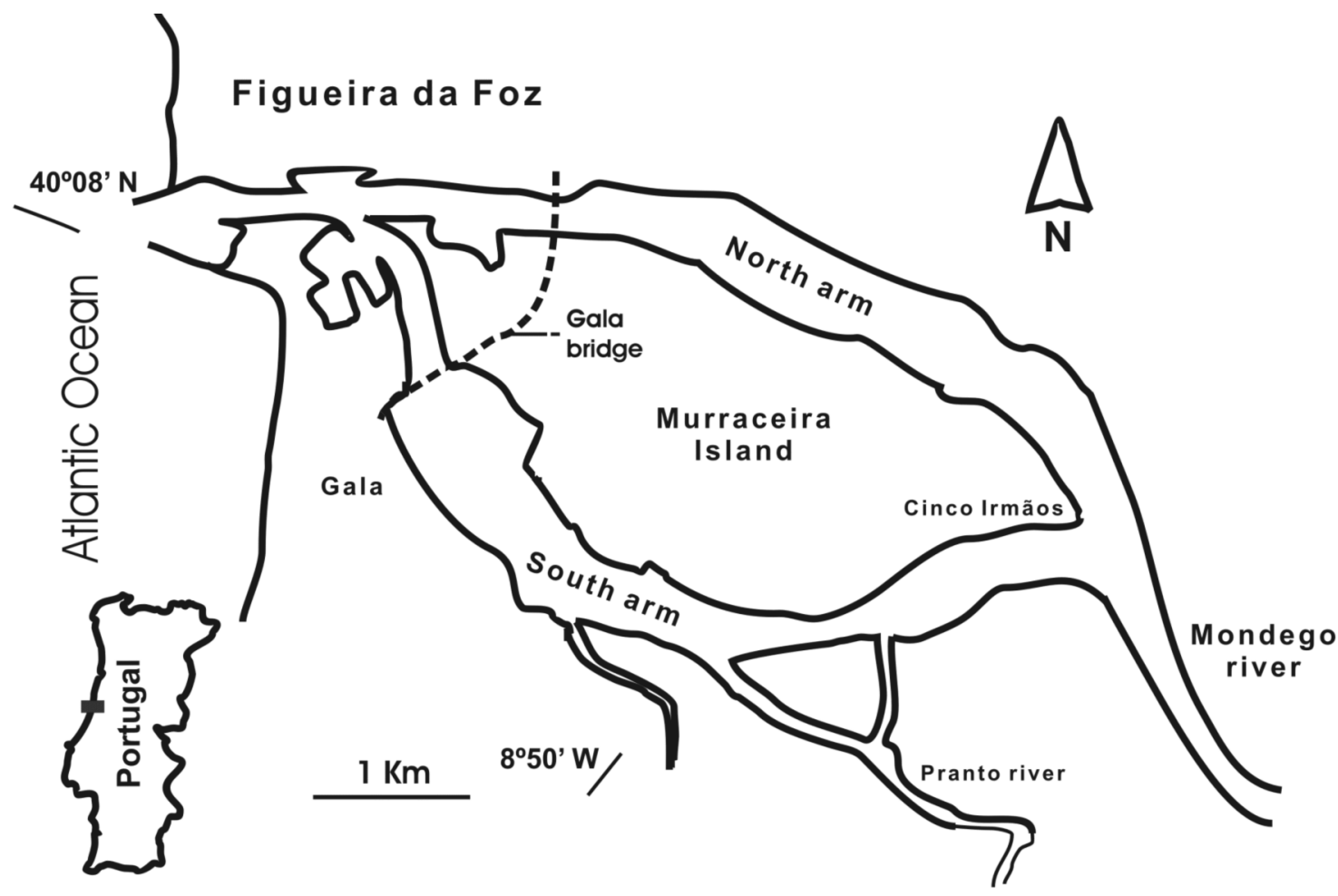

Fig. 1. Location map of Mondego estuary. 
The Mondego estuary is severely impacted by anthropogenic activities. Besides dredging related to harbour activities in the north arm which causes physical disturbance, this estuary supports several industries, salt works and aquacultures. It is also under eutrophication stress mainly caused by high nutrient inputs from the Pranto River (Fig. 1) (Marques et al. 2003), which drains agricultural fields. A nitrogen loading rate of $540 \mathrm{~kg} \mathrm{ha}^{-1} \mathrm{yr}^{-1}$ was estimated in the south arm (Flindt et al. 1997, Castro 2005).

The River Mira estuary is a narrow shallow tidal estuary located at the southwest of Portugal $\left(37^{\circ} 43^{\prime} \mathrm{N} 8^{\circ} 45^{\prime} \mathrm{W}\right)$ (Fig. 2). It runs for over $32 \mathrm{~km}$ and is ca. $150 \mathrm{~m}$ wide in the lower part and $30 \mathrm{~m}$ in the upper part, with a mean depth of ca. $6 \mathrm{~m}$. The depth varies from 5 to $10 \mathrm{~m}$ in the lower and middle segments and reaches $<3 \mathrm{~m}$ at the upper limit of the tidal influence.

This estuary is relatively undisturbed and free from large urban and industrial areas and hence may be less exposed to nutrient and chemical pollution. Main stress factors are due to some agriculture, cattle breeding, aquaculture practices, and wastewater from urban areas. Seasonal impacts due to tourism activities also occur at the mouth of the river. A maximum of $280 \mathrm{~kg} \mathrm{~N} \mathrm{ha}^{-1}$ was estimated to enter the estuary each yr (Costa et al. 2001). The salt marsh area was assessed from Casa Branca to the river mouth.

\section{Human population data}

Data on human population density in the vicinities of each estuarine watershed (Figueira da Foz municipality for Mondego and Odemira municipality for Mira) to measure human pressure in these ecosystems were obtained from the Portuguese National Institute of Statistics (INE) for yr 1930, 1940, 1950, 1960, 1981, 1991 and 2001. These data, although by no means a complete description of human densities and activities of the entire river basin watershed, could be taken as an approximate proxy that reflects human influence in the estuary watershed.

\section{Salt marsh mapping}

Salt marsh areas were delimited by visual interpretation in addition to fieldwork regarding seagrass cover and distri-

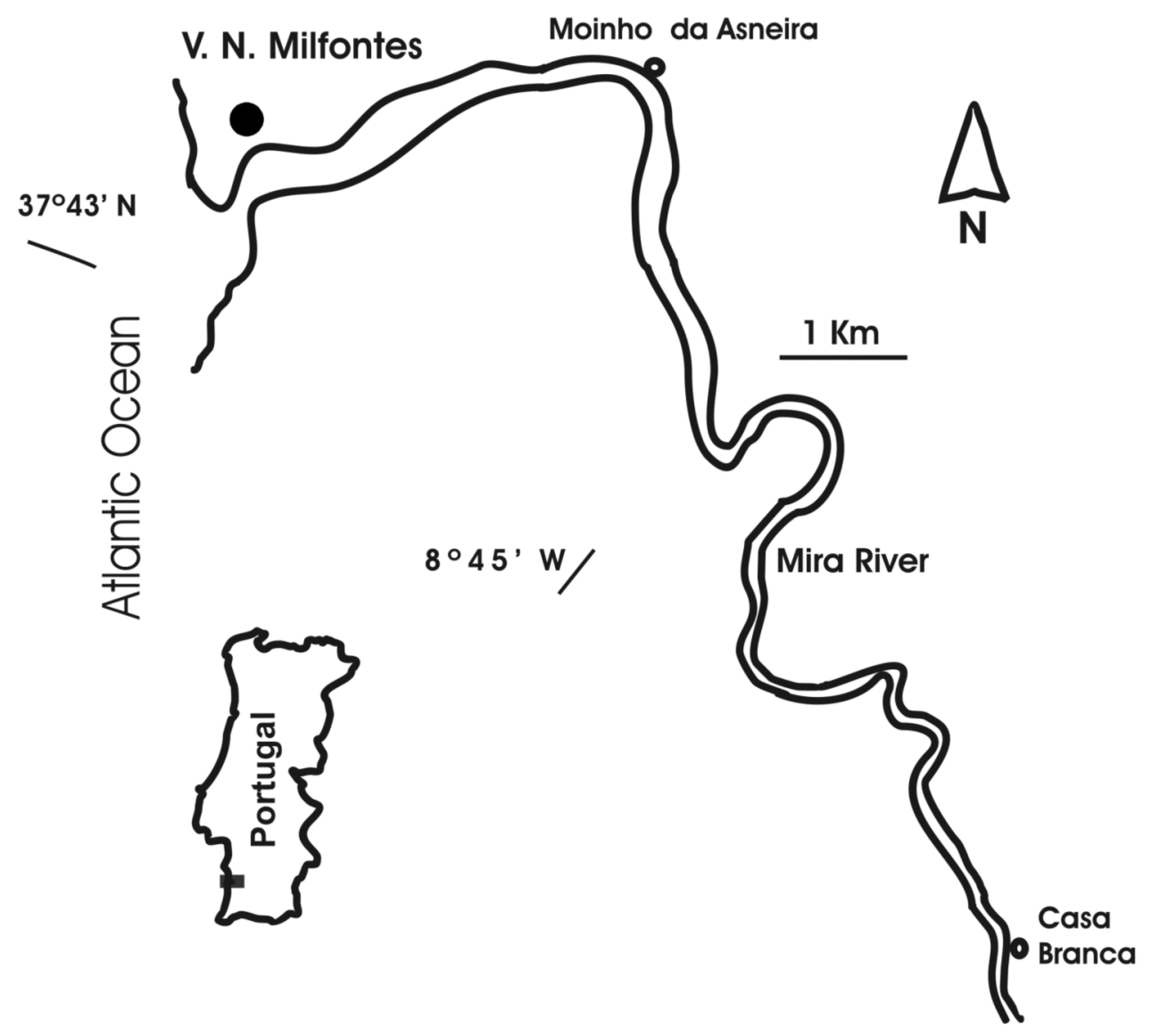

Fig. 2. Location map of Mira estuary. 
bution. Sets of aerial photographs were acquired for yr 1947, 1958, 1977, and 1998 (Mondego estuary) and yr 1958, 1969, 1985, and 1995 (Mira estuary). Using ArcView $^{\circledR}$ and ArcGis ${ }^{\circledR}$ Geographic Information Systems (GIS) software, the scanned photographs (resolution of 600 dpi) were geo-referenced based on 1:25000 Portuguese military maps, which represent coordinate accuracy of $10-25 \mathrm{~m}$ on the ground. Images were georeferenced selecting the maximum of matching points present in all years, e.g. houses, roads, bridges, and croplands. For both estuaries, a single composite image of the entire salt marsh area was created from each set of images. Marsh boundaries, defined as the limit of continuously vegetated marsh, were created using GIS procedures. Slump areas and small disjoint marsh areas were ignored. Both estuaries do not have a continuously vegetated marsh, so the total salt marsh area was calculated based on the sum of all identified salt marsh areas. The rectified images have a root mean square error of $<7 \mathrm{~m}$. Several factors influence the accuracy of the photo-interpretation, and image quality and scale, siltation, and water clarity and level, are examples of type errors associated to this methodology.

\section{Results}

\section{Mondego estuary}

Human density surrounding the Mondego estuary watershed was always higher than in the Mira estuary since 1930
(Fig. 3). Aerial surveys of the Mondego estuary in 1947 clearly showed that it was already under anthropogenic pressure at that time because large areas of natural estuarine land (Murraceira Island) were transformed by several agriculture practices (Fig. 4).

Salt marshes were observed in both arms with larger areas detected in the south arm near Cinco Irmãos bifurcation. A total of 129 ha were estimated for the marsh area in 1947, which extended $2.9 \%$ during the period 19471958 (Fig. 5). In 1958, the estuary was less silted up and more vegetation beds were mapped, but the marsh location was generally the same. Marsh loss occurred after this yr (Fig. 4 and 5). Between 1958 and 1977 the estuary lost ca. $13 \%$ of the marsh area, decreasing to a total of 115 ha. The north arm was more severely affected by land use changes. In 1998, the last photographic survey, marsh losses were again evident when compared to the previous survey. Major losses occurred in the north arm (Fig. 4), but changes were also observed in the southern subsystem. Since 1958, the Mondego estuary lost almost $17 \%$ of the marsh area, ending up with a total of 111 ha in 1998.

\section{Mira estuary}

No substantial changes within the Mira salt marsh were evident from the aerial photographs (Fig. 5 and 6). Over 37 years since 1958 the marsh expanded only $1.5 \%$. Salt marsh area estimated from aerial photography was 175 ha in 1995. In 1958, this value was 173 ha. During the period 1958-1969 the marsh retreated by $1.7 \%$, recovering the

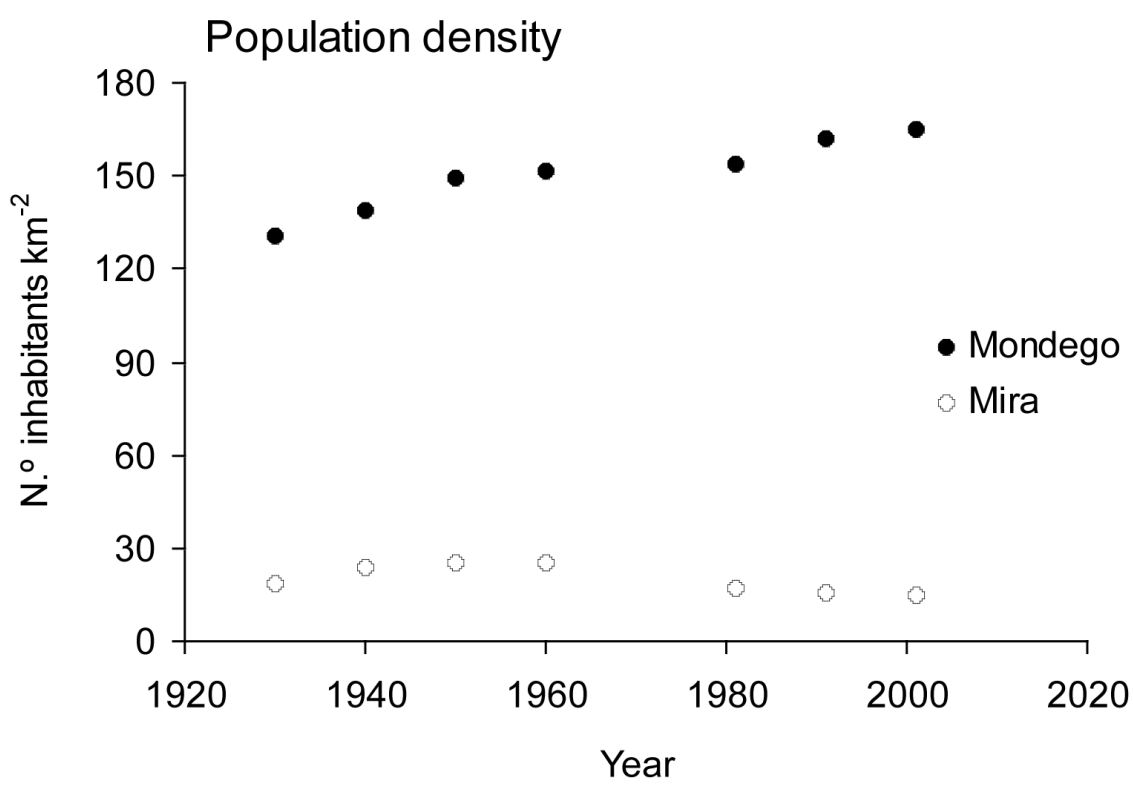

Fig. 3. Data on population density in the Mondego (Figueira da Foz Municipality) and Mira (Odemira Municipality) estuarine watersheds for the 1930-2001 period. 


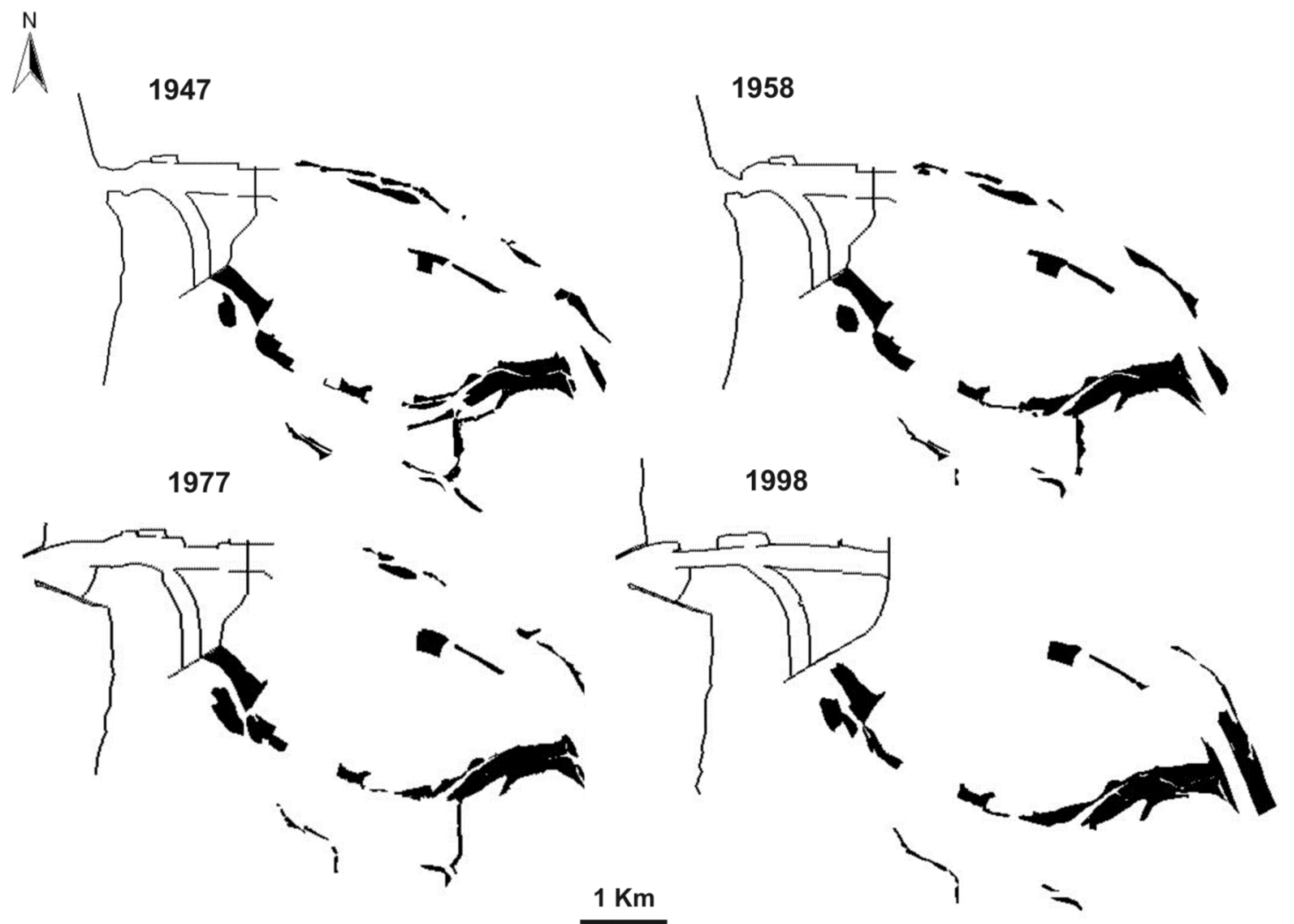

Fig. 4. Salt marsh distribution in the Mondego estuary.

same area during the following $17 \mathrm{yr}$. The position of the marsh was relatively constant in all the aerial surveys.

\section{Discussion}

The analysis of salt marsh cover and changes in the Mondego and Mira estuaries provide a comprehensive picture of human occupation effects on these natural ecosystems. Periods of salt marsh extension and retreat are natural phenomena in estuaries. However, urbanization of the coastal zone is becoming increasingly widespread all over the world and interfering with the natural dynamics of these ecosystems. Mondego and Mira estuaries represent quite different situations regarding human pressure.

The differences observed during the period 1947-1958 for the Mondego estuary could be a result of errors that are inherent to the photo interpretation method. After this period, marsh loss was more severe and mainly attributable to land reclamation. The watershed surrounding the Mondego estuary comprises a major urban area (Figueira da Foz municipality) that has been constantly growing over the past decades owing to economical activities and house building. Natural substrata was claimed to sustain urban and industrial expansion and consisted in the construction and improvement of roadways and bridges, dredging activities, construction of a river bed, and aquaculture farms. Some lost marshes in the south arm, however, could not be attributed to direct land claim and natural system dynamics; indirect human impacts (pollution, eutrophication, sediment reworking and erosion) and mapping error are all probable causes of such changes. Sediment sentinels measured by Castro et al. (in press) showed a clear increase in $\% \mathrm{~N}, \delta^{15} \mathrm{~N}$ and $\mathrm{Pb}$ concentrations in the past six decades, reflecting land-use of this watershed.

The Mondego estuary has suffered for many years of regularization works on it and on the fluvial sector. During the past three decades, engineering works included several dams, a new river bed, and a parallel water supply channel for agricultural and industrial purposes. These works caused morphological, hydrological and sedimentary modifications in the estuary and river system (Cunha et al. 1997, Dinis and Cunha 1999). The potential for modifications of coastal habitats by the addition of some of these structures have complex and widespread consequences on coastal environments (Glasby and Connell 1999) with significant impacts in its biological and ecological quality. The accretion rates, estimated by Castro et al. (in press) 


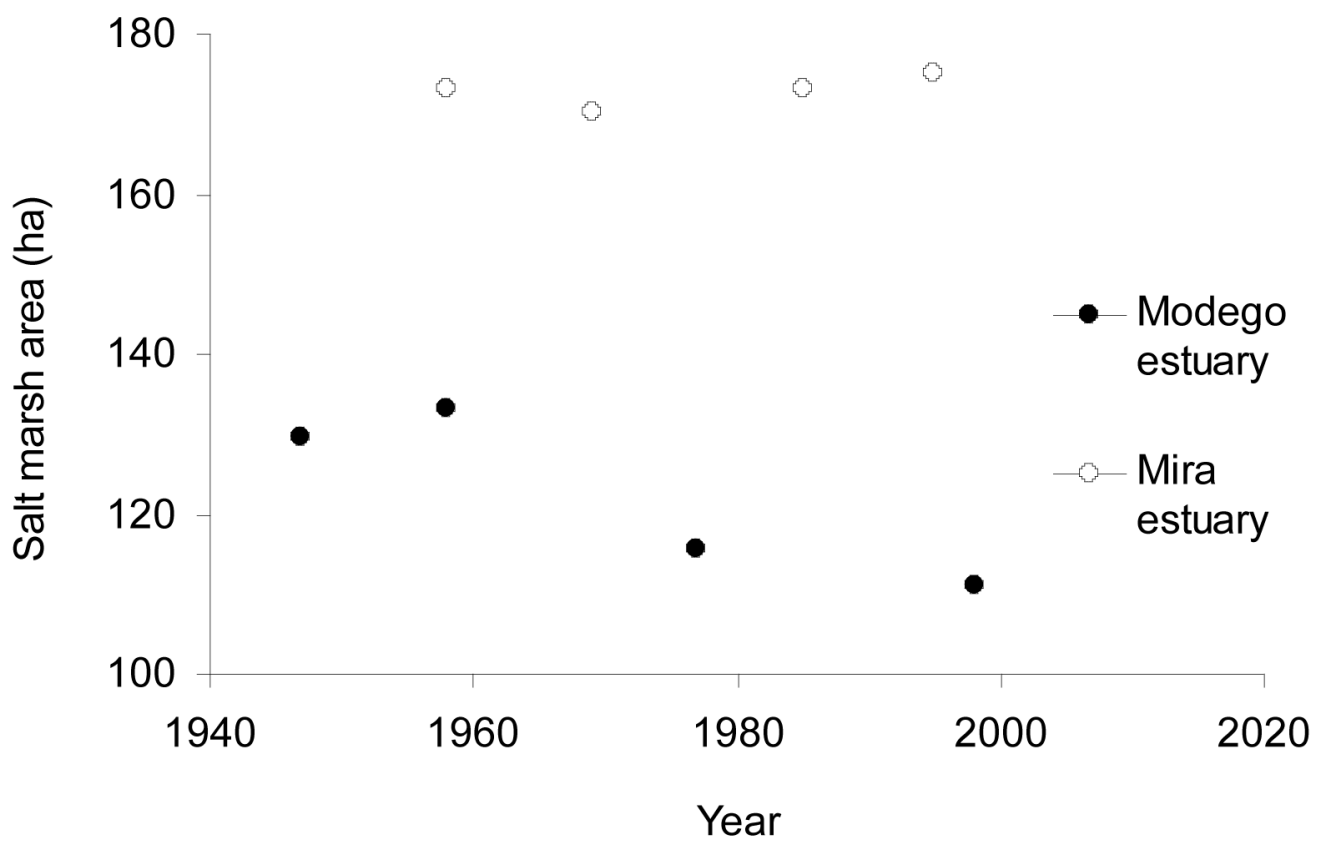

Fig. 5. Salt marsh area evolution in each estuary.

across the period $1920-2000$, were $0.55 \mathrm{~cm} \mathrm{yr}^{-1}$ for Mondego and $0.68 \mathrm{~cm} \mathrm{yr}^{-1}$ for Mira. Sediment transport downestuary was therefore faster in Mira than in Mondego, in spite of the greater human activity in the Mondego watershed.

The contamination with pesticides and fertilizers due to intensive agriculture is also a major environmental problem in the Mondego lower basin. The south arm is more affected by agriculture pollution, receiving waters loaded with pesticides and fertilizer pollutants (mainly nitrogen forms) from the Mondego and Pranto rivers (Marques et al. 2003).

The results of the aerial surveys of the Mira estuary showed a different trend on salt marsh evolution. This eco- system is relatively undisturbed by anthropogenic activities, and marsh variation could follow natural dynamics rather than having been affected by human impacts. The observed changes could also be a result of the measurement error inherent to the mapping method.

There was no visible detriment in marsh area. However, Castro et al. (in press) observed a small but steadily increase in $\% \mathrm{~N}, \delta^{15} \mathrm{~N}$ and $\mathrm{Pb}$ concentrations in sediments in recent decades, which point to an increase in land-derived pollution. Even though population density decreased in the Mira watershed, the total number of residences suffered a substantial increase, especially in the coastal zone. A growing urban area is observed in the mouth of the river. The area is becoming very popular in the summer season
1958

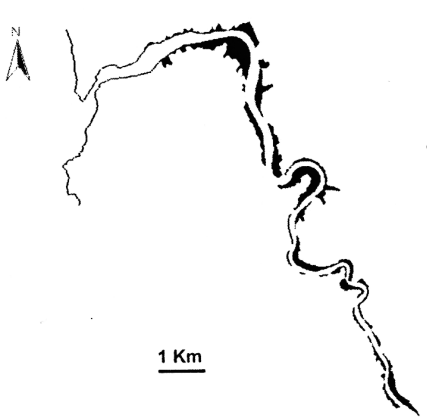

1969

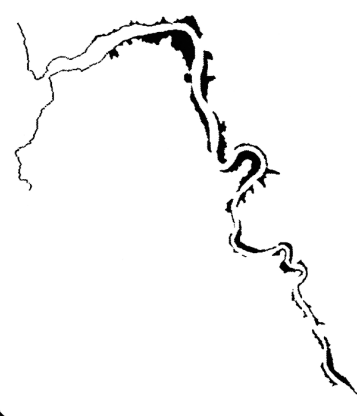

1985

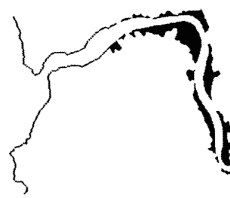

1995

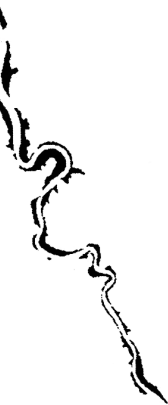

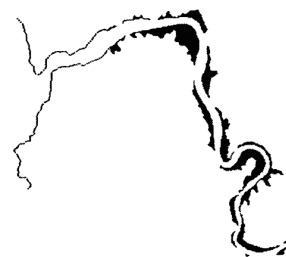

3

Fig. 6. Salt marsh distribution in the Mira estuary. 
when recreational activities, like boat traffic, fishing, and bivalve and worm collection increase in the mouth of Mira and disturb the ecosystem. Upstream areas are commonly used as pastures and animal wastes are known to be a considerable source of nutrient pollution that could lead to severe long-term consequences in the ecosystems.

Sustained nutrient enrichment into salt marshes, especially originated by non-point sources, causes effects that are very difficult to assess. These impacts disturb the natural dynamics of estuarine producers, marsh plant structure, seagrass meadows, and food webs but are usually detected after many years (Flindt et al. 1999, Andersen et al. 2002, Deegan 2002).

\section{Conclusions}

Long-term changes in the Mondego estuary revealed a decline in the salt marsh area after 1958 associated to increasing human pressure in the region. Most marsh loss in this estuary was directly related to land claim. Organic and chemical pollution due to salt exploitation, aquaculture farming, agriculture, urban and industrial expansion, fishing activities and tourism are also important environmental stressors. Although major changes were not found in the total salt marsh area of the Mira estuary, some conditions need to be closely surveyed in the future. Sediments record of $\% \mathrm{~N}, \delta^{15} \mathrm{~N}$ and $\mathrm{Pb}$, clearly confirmed an increase of anthropogenic disturbance in this ecosystem. Housing development in the coast and consequent domestic waste production, recreational and fishing activities and nutrient pollution from animal-feeding effects need to be better assessed in order to predict future trends in this ecosystem.

Acknowledgements - This work was carried out in the scope of the POCTI/BSE/2000/36087 project "Assessing key-habitat loss due to eutrophication in the Mondego and Mira estuaries". The authors thank Maria J. Martins and Engo José Gaspar for their help with the GIS procedures, and two anonymous reviewers for their comments and suggestions.

\section{References}

Adam, P. 2002. Saltmarshes in a time of change. - Environ. Conserv. 29: 39-61.

Allen, J. R. L. 2000. Morphodynamics of Holocene salt marshes: a review sketch from the Atlantic and Southern North Sea coasts of Europe. - Quaternary Sci. Rev. 19: 1155-1231.

Andersen, D. M., Glibert, P. M. and Burkholder, J. M. 2002. Harmful algal blooms and eutrophication: nutrient sources, composition, and consequences. - Estuaries 25: 704-726.

Anon. 2001. Eutrophication in Europe's coastal waters. Topic report 7/2001. - European Environment Agency, Copenhagen.

Anon. 2004. Living with coastal erosion in Europe: sediment and space for sustainability. - URL: www.eurosion.org. (Accessed 15/09/2006).
Anon. 2005. The European environment: state and outlook 2005. - European Environment Agency, Copenhagen.

Anon. 2006. The changing faces of Europe's coastal areas. TR N. ${ }^{\circ}$ 6/2006. - European Environment Agency, Copenhagen.

Anon. 2006. Priority issues in the Mediterranean environment. TR N. ${ }^{\circ} 4 / 2006$. Copenhagen

Bertness, M. D., Ewanchuk, P. J. and Silliman, B. R. 2002. Anthropogenic modification of New England salt marsh landscapes. - P. Natl. Acad. Sci. 99: 1395-1398.

Bowen, J. L. and Valiela, I. 2001. The ecological effects of urbanization of coastal watersheds: historical increases in nitrogen loads and eutrophication of Waquoit Bay estuaries. - Can. J. Fish. Aquat. Sci. 58: 1489-1500.

Castillo, J. M., Rubio-Casal, A. E., Luque, C. J. et al. 2002. Wetland loss by erosion in Odiel marshes (SW Spain). - J. Coastal Res. 36: 134-138.

Castro, P. 2005. Assessing key-habitat loss due to eutrophication in the Mondego and Mira estuaries. PhD dissertation, Coimbra University.

Castro, P., Valiela, I. and Freitas, H. In press. The use of sedimentary $\% \mathrm{C}, \% \mathrm{~N}, \mathrm{~d} 15 \mathrm{~N}$, and $\mathrm{Pb}$ concentrations to assess historical changes in anthropogenic influence on Portuguese estuaries. Environ. Pollut. (2006), doi:10.1016/ j.envpol.2006.09.011.

Constanza, R., d'Arge, R., de Groot, R. et al. 1997. The value of the world's ecosystem services and natural capital. - Nature 387: 253-260.

Cooper, N. J., Cooper T. and Burd, F. 2001. 25years of salt marsh erosion in Essex: Implications for coastal defense and nature conservation. - J. Coastal Conserv. 9: 31-40.

Costa, M. J., Catarino F. and Bettencourt, A. 2001. The role of salt marshes in the Mira estuary (Portugal). - Wetlands Ecol. Man. 9: 121-134.

Cox, R., Wadsworth, R. A. and Thomson, A. G. 2003. Longterm changes in salt marsh extent affected by channel deepening in a modified estuary. - Cont. Shelf Res. 23: 18331846.

Cunha, P. P., Pinto, J. and Dinis, J. L. 1997. Evolução da fisiografia e ocupação antrópica na área estuarina do Rio Mondego e região envolvente (Portugal centro-oeste), desde 1947. - Territorium 4: 99-124.

Deegan, L. A. 2002. Lessons learned: The effects of nutrient enrichment on the support of nekton by seagrass and salt marsh ecosystems. - Estuaries 25: 727-742.

Dinis, J. L. and Cunha, P. P. 1999. Sedimentologia e hidrodinâmica dos sub-sistemas estuarinos do Mondego (Portugal central). - Rec. Híd. 20: 37-49.

Duarte, C. M. and Chiscano, C. L. 1999. Seagrass biomass and production: a reassessment. - Aquat. Bot. 65: 159-174.

Ekebom, J. and Erkkilä, A. 2003. Using aerial photography for identification of marine and coastal habitats under the EU's Habitats Directive. - Aquat. Conserv. Mar. Fresh. Ecos. 13: 287-304.

Flindt, M. R., Kamp-Nielsen, L., Marques, J.C. et al. 1997. Description of the three shallow estuaries: Mondego River (Portugal), Roskilde Fjord (Denmark) and the Lagoon of Venice (Italy). - Ecol. Model. 102: 17-31.

Flindt, M. R., Pardal, M. A., I. Lillebø, A., et al. 1999. Nutrient cycling and plant dynamics in estuaries: a brief review. - Acta Oecol. 20: 237-248.

Glasby, T. M. and Connell, S. D. 1999. Urban structures as marine habitats. - Ambio 28: 595-598. 
Jiménez, J. A., Sánchez-Arcilla, A., Bou J. et al. 1997. Analysing short-term shoreline changes along the Ebro Delta (Spain) using aerial photographs. - J. Coastal Res. 13: 1256-1266.

Klemas, V., Dobson, J. E., Ferguson, R. L. et al. 1993. Coastal land cover classification system for the NOAA watch change analysis project. - J. Coastal Res. 9: 862-872.

Marques J. C., Nielsen, S. N., Pardal M. A. et al. 2003. Impact of eutrophication and river management within a framework of ecosystem theories. - Ecol. Model. 166: 147-168.

Mas, J. F. 2004. Mapping land use/cover in a tropical coastal area using satellite sensor data, GIS and artificial neural networks. - Estuar. Coast. Shelf Sci. 59: 219-230.

O'Regan, P. R. 1996. The use of contemporary information technologies for coastal research and management - a review. $-\mathrm{J}$. Coastal Res. 12: 192-204.
Robbins, B. 1997. Quantifying temporal change in seagrass aerial coverage: the use of GIS and low resolution aerial photography. - Aquat. Bot. 58: 259-267.

Schwimmer, R. A. 2001. Rates and processes of marsh shoreline erosion in Rehobth Bay, Delaware, U.S.A. - J. Coastal Res. 17: 672-683.

Short, F. T. and Burdick, D. M. 1996. Quantifying eelgrass habitat lossin relation to housing development and nitrogen loading in Waquoit Bay, Massachusetts. - Estuaries 19: 730-739.

Udy, J. W., Dennison, W. C., Lee W. J. L. et al. 1999. Responses of seagrass to nutrients in the Great Barrier Reef, Australia. Mar. Ecol. Prog. Ser. 185: 257-271.

Vitousek, P. M., Aber, J. D., Howarth, R. W. et al 1997. Human alterations of the global nitrogen cycle: sources and consequences. - Ecol. Appl. 3: 737-750. 